$9(1)(2020) 8-12$
Indonesian Journal of Early Childhood
Education Studies

\title{
The Influence of Picture Book to the Storytelling skill of Preschool Children
}

\author{
Eka Mei Ratnasari ${ }^{\bowtie}$ \\ DOI: http://dx.doi.org/10.15294/ijeces.v9i1.37805
}

Institut Agama Islam Negeri Metro Lampung, Indonesia

\section{History Article \\ Submitted 27 February 2020 Revised 31 May 2020 Accepted 4 June 2020}

\section{Keywords}

Preschool Children; Picture Book; Storytelling Skill

\begin{abstract}
The benefit of storytelling activity to children's skill development is to provide a positive contribution to children's language skill. This research aimed to determine the impact of the picture book to the storytelling skill of children aged 4-5 years. The research subjects consisted of two kindergartens in Yogyakarta (Pringwulung and Cempaka kindergarten) Indonesia. The participants are 40 children. The data were used quasi-experimental research design. The research data obtained were analyzed with t-test through SPSS 16 program to see the differences between the experimental group and the control group. The result of this research was a significant influence of using picture book on the storytelling skill of preschool children. The recommendation from the result of this research was provided to parents and teachers particularly to develop children's communication skill and practitioner in the discussion that especially emphasized addressing the need to increase opportunities for storytelling skill of preschool children in good stimulation.
\end{abstract}

\section{How to Cite}

Ratnasari, E. M. (2020). The Influence of Picture Book to the Storytelling skill of Preschool Children. Indonesian Journal of Early Childhood Education Studies, 9(1), 8-12.

Correspondence Author:

E-mail: ekameiratnasari1@gmail.com

p-ISSN 2252-8415

e-ISSN 2476-9584 


\section{INTRODUCTION}

Humans cannot be separated from the use of language. Language can be used for various needs such as business, information, and education. Language is very important to use in communicating. Through language, people can understand and understand each other. A language is a form of communication, communication can be oral, written or a sign based on a system that comes from symbols (Santrock, 2007). A language is a communication tool used ranging from adults to children. Children's language skills began to develop rapidly during the pre-school period. The number of children's vocabulary continues to grow, the length of the sentence also increases and master grammar (Morrison, 2012). Through language, children can develop the ability to socialize with others. There are two types of language development, receptive and expressive language. Receptive language refers to individual efforts to accept and understand language input. While expressive language refers to the child's efforts to communicate and convey feelings and opinions to others. Language skills include four aspects which consist of listening, speaking, reading and writing. These four aspects of skills constitute a single entity. Language development can develop optimally according to the stage of development if given appropriate and appropriate stimulation in children. Speaking is a form of language using articulation that is used to convey intentions/meanings (Hurlock, 1978). When speaking, children will learn to say articulation or words, expressions, and rhythms to convey their thoughts and feelings. In addition, children will also get a lot of vocabularies. At this time, the ability to speak becomes more crucial. The development of language skills must be the main choice so as not to lag behind the global competition. Through talking, communication will occur between one child and another. Hurlock (1978) said that the ability to speak becomes an important need in the life of a child, the need is to be part of a social group. When children are not fluent in speaking, children use other ways to communicate with members of social groups, but the role given by children in the group will be small. The development of speech is very important and is needed by the child to facilitate speaking skills. Therefore, the speaking ability of children should to be stimulated continuously.

In relation to the ability to speak children, retelling a story will certainly add to the development of children's abilities in language. Musfiroh (2005) explains if the child's ability to retell the contents of the story is good, the better the child's understanding of the story is. When the children who retell a story in a detailed and coherent manner, it gets better the memory, analysis, and way of thinking systematically. In line with this opinion, Mustakim (2005) explained that when the retelling was carried out, the teacher aroused the role of children's language to use spoken language appropriately. Storytelling is the development of spoken language. The development of the ability to tell stories can be through the use of book. Graham (2010) said the most child-friendly media, especially children is the book. Picture books are the first books owned by children in developing and exploring their world The book material is tailored to the child's age level. Gnjatovic (2015) argues that Vygotsky explained that imaginative images that can provide the internal language of human emotions. All life experiences are colored with emotion. People use language to form experiences and interact socially and communicate their stories to others. Storytelling is an excellent activity in child language development. Atta-Alla (2012); Kim (2010) explains that storytelling is an effective activity in language development, this can be done through the use of books. Reed et al. (2015) said that telling stories through picture books in peer groups can stimulate reasoning for children aged 4.5 to 6 years. The use of books makes the story more fun, interesting and contextual. Retelling a story will certainly add to the development of the ability of children in language.

In general, the picture book is a book owned by the majority of children. Kotaman \& Balci (2016) elaborated the picture book as a type of book chosen by adults to read together with children. The picture book is a book that has content of drawing and text. Picture book consists of more drawing and less text (Biddle et al. 2014; Mitchell, 2003). Reed et al. (2015) stated that storytelling through picture book in the same age group can stimulate reasoning for 4.5-6 years old children. By using picture book, storytelling becomes more fun, interesting, and contextual. However, the picture book is not used in teaching activity. Based on the interview from the teacher of Pringwulung kindergarten, the development of activities that explore the ability to tell the story is often abandoned. Most educators only focus on reading and writing skills and the use of children's worksheets. This happens because of the demands of parents who expect their children can already read and write when entering elementary school (SD). This phenomenon does not only occur in PAUD Integrated TK-KB 
Aisyiah Bustanul Athfal Pringwulung Yogyakarta but occurs in other areas as well. This phenomenon is supported by the results of research conducted by Istiyani (2013) about parents and educational institutions in Pekalongan district to involve children in private tutoring activities to improve reading, writing and numeracy (CALISTUNG) even this activity has been followed by the children since being in group A. Other than that, the teacher explained that the availability of the picture book in the school is poor and there is no special time to read books together. This explanation is based on observation result done by the researcher in two schools in Yogyakarta that show the use of media is very minimum on communication learning process. This can be seen from the media that are available in school, which are media that cannot maximize children's communication skill. Most of the available media is to develop children's motor skills and cognitive development. The used of media in developing children's storytelling skills in kindergarten is still really minimum, the activities are focused more on LKA (Lembar Kerja Anak or Children Work Sheet). Teachers provide children's magazine as a magazine of CEPPI (Cepat Pintar Untuk Anak TK) which originated from IGTKI (Ikatan Guru Taman Kanak-kanak Indonesia). Then, teachers instruct for the magazine to be read at home. This research aimed to determine the impact of the picture book to the storytelling skill of children aged 4-5 years Therefore, this research will discuss the issues related to the teaching process to determine the influence of using the picture book to the storytelling skill of preschool children.

\section{METHOD}

The type of research in this research was quasi-experimental. In quasi-experiment, the researchers used the control group and experimental group but did not randomly enter the participants into both groups (Cresswell, 2016). It said that quasi-experiment because not all variables can be controlled or measured. In the experimental design, the ultimate goal is to examine the impact of a treatment (or an intervention) on the results of the study, controlled by other factors which may also affect the outcome (Cresswell, 2016). In quasi-experiments have a control group, but cannot function fully to control the outside variables that affect the implementation of the experiment.

This research was done in ABA Pringwulung and ABA Cempaka Yogyakarta. The subjects in this study using purposive sampling technique, the purposive sampling technique is a sample determination technique with certain considerations. The subjects of this research were 4-5 years old children, 40 in total. The subjects were divided into 20 children in the experiment group in ABA Pringwulung and 20 children in the control group in ABA Cempaka. The experiment group used the picture book, while the control group used the conventional group. The data of this research consisted of pre-test data and post-test of children's storytelling skill. The technique of data collection used in this research was through observation while data analysis was by t-test which uses SPSS 16 program.

Data collection steps are as follows: Compile observation instruments for children's speaking and storytelling skills. Revise the children's storytelling ability observation instrument. Give the pretest to the experimental group and the control group to find out the initial information about the level of child development. Give treatment to both groups. The experimental group was given treatment using pictorial storybook media and for the control group using learning using question and answer activities and storytelling without using tools.

Give a post-test to both groups. Post-tests are carried out as an illustration of the development that has been achieved by the child. The results of this post-test are compared with the results of the pretest so that it will be known how much influence the use of illustrated storybooks is applied in the learning process. Data collection is a major step in research. Data collection techniques used in this study are observations.

\section{RESULT AND DISCUSSION}

This research is aimed to determine the impact of the picture book to the storytelling skill of children aged 4-5 years. The usage of the book itself can be observed through experiment group and control group. The data in this research include pre-test data score and post-test of children storytelling skill. Collected data were processed with the SPSS 16 program.

The result based on normality test obtained the value of $p$ in Kolmogorov-Smirnov was determined, which showed whether the data distribution is normal or not. The requirement of normally distributed data is when $\mathrm{p}$-value gained on calculation is larger than 5\% (0.05) significance. The result of calculation on children's storytelling skill had the pre-test significant value on experiment and control group of 0.096 and 0.148 (p) $>0.05$ which mean the data were normally 
distributed. Subsequently, on the post-test, the significant values of storytelling in the experiment and control group were 0.065 and 0.052 (p) $>0.06$ which mean the data were normally distributed. Thus, it can be concluded that both data result from speaking storytelling skills are normally distributed.

The next research data was a homogeneity test done with Levene's test. Acceptance or rejection of Ho can also be seen through probability value with criteria of significant value on output is higher than 0.05 then data is homogenous while if it is smaller than 0.05 that data is not homogenous. The result shows the pretest homogeneity of children's storytelling skill observed through the result of pretest and post-test in experiment group and control group had the value of sig $>$ a $(0.804$ and $0.923>0.05)$ which mean data are homogeneous.

Hypotheses test done was t-test. Should the hypotheses test result yield difference, this means the use of picture book impacts to children's storytelling skill. The result is demonstrated in the table below which stated that the significance value $<0.05$. Thus, the picture book impacts children's storytelling skill.

In this research, Pringwulung kindergarten as the experiment group was given the treatment of picture book, while in Cempaka kindergarten, the conventional method was used. The result of the research showed that there was a significant influence from using the picture book to children's storytelling skill. The hypotheses calculation indicated that kindergarteners which provided with the picture book as a media experienced a greater increase in storytelling skill compared to before teaching. The increase of storytelling skill on children happened because of the learning process with the picture book as the media is one of the strategies that can be chosen to develop the principle of learning while studying and makes children as the center of learning in education for children in early childhood. This means that the learning process was gained through activities done independently or in the group.

The result of this research was supported by research of Reed et al. (2015) which pointed out that storytelling through the picture book on the same age group can stimulate reasoning for 4.5-6 years old children. The drawing on picture book will be more effective for children to understand the story compared to a story that only includes text. Before the research is conducted, the pretest is done first to discover the children's skill in general. According to the result summary of pretest for storytelling skill with an error limit of
0.05 , it can be concluded that $\mathrm{H} 0$ is accepted because the result is the value of Sig $>$ a. Based on the summary of the result of t-test independent sample pretest of storytelling skill of children on experiment group and control group has significant value $(0.701>0.05)$. In contrast to the result of storytelling skill of children with the picture book as the media gained from the post-test result with error limit of 0.05 , then it can be concluded that $\mathrm{HO}$ is rejected because it was found that the value of $\mathrm{Sig}<\mathrm{a}(0.003<0.05$. Thus, a difference occurs between experiment group and control group in terms of children's storytelling skill.

This research is supported by the results of research conducted by Gufron \& Mas'udah (2015) which explains that a teacher needs media that can attract children's attention. The media used is the picture book. The purpose of this stu$\mathrm{dy}$ is to improve the ability to tell children using picture book, the results can be seen from cycle I to cycle II which increased to $75.59 \%$. It can be concluded that the use of pictorial picture book media can improve the ability to tell a child. Another study conducted by Afnida, et al. (2016) on the use of picture book in the development of the language of children in kindergarten $\mathrm{A}$ in Banda Aceh. This study explains that the use of picture books used by teachers can improve the language skills of children. Interactions that occur between teachers and students can be well established through the use of picture book. So the level of language ability of children increases.

As the child recounts the reading story, the child has the opportunity to develop his understanding through the content of the story associated with the expression (Miller \& Pennycuff, 2008). More specific exposure is given by Machado (2013) which explains that the purpose of telling stories is to increase the comfort of the child in talking, to make the child familiar with the story, to encourage the child to tell the story, to improve the vocabulary of the child, and to increase the confidence of the person who tells the story. Donoghue (2009) who explained that in general story can stimulate the imagination, especially useful for developing communication skills, improve language skills and motivate the students to read. Similar exposures described by Vygotsky via (Gnjatovic, 2015) about imaginative images can give an internal language of human emotions. All life experiences are colored with emotion. People use language to form experiences and interact socially and communicate their stories to others. One of the images that can be used is the picture book. Storytelling through picture books together with peers can stimulate reasoning for 
children aged 4.5 to 6 years (Reed et al., 2015). The selection of pictorial picture book media is an appropriate choice in developing the language skills of children who in this study develop the ability to speak and tell children.

\section{CONCLUSION}

Based on data analysis and discussion, it can be concluded that the use of picture book impacts the storytelling skill of children. This is proven from the result of t-calculation on experiment group. The significant value determined is $<0.05$ thus it can be concluded that there is a significant difference between pretest and post-test result on the experiment group. Hence, it can be stated that there is a significant increase in storytelling skill on the experiment group through the use of picture book. The recommendation from the result of this research can be beneficial to parents, teachers, schools and the surrounding environment of the children, particularly to develop children's communication skill.

\section{REFERENCES}

Afnida, M., Fakhriah, F., \& Fitriani, D. (2016). Penggunaan buku cerita bergambar dalam pengembangan bahasa anak pada TK A di Banda Aceh. Jurnal Ilmiah Mahasiswa Pendidikan Anak Usia Dini, 1(1), 52-59.

Atta-Alla, M. (2012). Integrating language skills through storytelling. English Language Teaching, (5)12, 1-13.

Biddle, K. A. G., Nevarez, A. G., Henderson, W. J. R., \& Vallero-Kerrick, A. (2014). Early Childhood Education Becoming A Professional. USA: SAGE Publications, Inc.

Cresswell, J. W. (2016). Research design pendekatan metode kualitatif, kuantitatif dan campuran edisi keempat. (Terjemahan Achmad Fawaid \& Rianayati K.P). Yogyakarta: Pustaka Pelajar. (edisi asli diterbitkan tahun 2014 oleh SAGE Publication, Inc.)

Donoghue, M. R. (2009). Language arts: integrating skill for classroom teaching. Thousand Oaks: Sage Publication, Inc.

Gnjatovic, D. (2015). Stories in different domains of child development. Child care facility University of Malta. Original scientific paper UDK: 37.022

Graham, B., \& Cook, S. (2010). Rethinking Curating: Art after New Media-Leonardo Books. The MIT Press.

Gufron, M. \& Mas'udah (2015). Meningkatkan kemampuan bercerita melalui media buku cerita bergambar anak kelompok A. PAUD Teratai, 4(2), 1-5.

Hurlock, B. E. (1978). Perkembangan Anak Jilid 2. Jakarta: Erlangga.

Istiyani, D. (2013). Model pembelajaran membaca menulis menghitung (CALISTUNG) pada anak usia dini di kabupaten Pekalongan. Jurnal Penelitian, 10(1), 1-18.

Kotaman, H., \& Balc1, A. (2017). Impact of storybook type on kindergarteners' storybook comprehension. Early Child Development and Care, 187(11), 1771-1781.

Machado, J. M. (2013). Early childhood experiences in language arts early literacy $\left(10^{\text {th }} \mathrm{ed}\right)$. Wadsworth. Cengage Learning.

Miller, S., \& Pennycuff, L. (2008). The power of story: using storytelling to improve literacy learning. Journal of cross-disciplinary perspective in education, 1(1), 36-43.

Morrison, S. (2012). Dasar-dasar pendidikan anak usia dini edisi kelima. (Terjemahan Suci Romadhona \& Apri Widiastuti). Jakarta: PT. Indeks. (Edisi asli diterbitkan tahun 2008 oleh Pearson Education, Inc. New Jersey).

Musfiroh, T. (2005). Bercerita untuk Anak Usia Dini. Jakarta: Departemen Pendidikan Nasional, Direktorat Jenderal Pendidikan Tinggi, Direktorat Pembinaan Pendidikan Tenaga Kependidikan dan Ketenagaan Perguruan Tinggi.

Mustakim, M. N. (2005). Peranan cerita dalam pembentukan perkembangan anak TK. Jakarta: Departemen Pendidikan Nasional, Direktorat Pendidikan Nasional, Direktorat Jenderal Pendidikan Tinggi, Direktorat Pembinaan Pendidikan Tenaga Kependidikan dan Ketenagaan Peguruan Tinggi.

Reed, H. C., Hurks, P. P. M., Kirschner, P. A., \& Jolles, J. (2015). Preschoolers' causal reasoning during shared picture book storytelling : a crosscase comparison descriptive study. Journal of Research in Childhood Education, 29(3), 367-389,

Santrock, J. W. (2007). Perkembangan anak jilid 1. (Terjemahan Mila Rachmawati \& Anna Kuswanti). Jakarta: Erlangga. (edisi asli diterbitkan tahun 2007 oleh McGraw-Hill Companies Inc.) 